Historic, Archive Document

Do not assume content reflects current scientific knowledge, policies, or practices. 



\section{Cromwell Gardens}
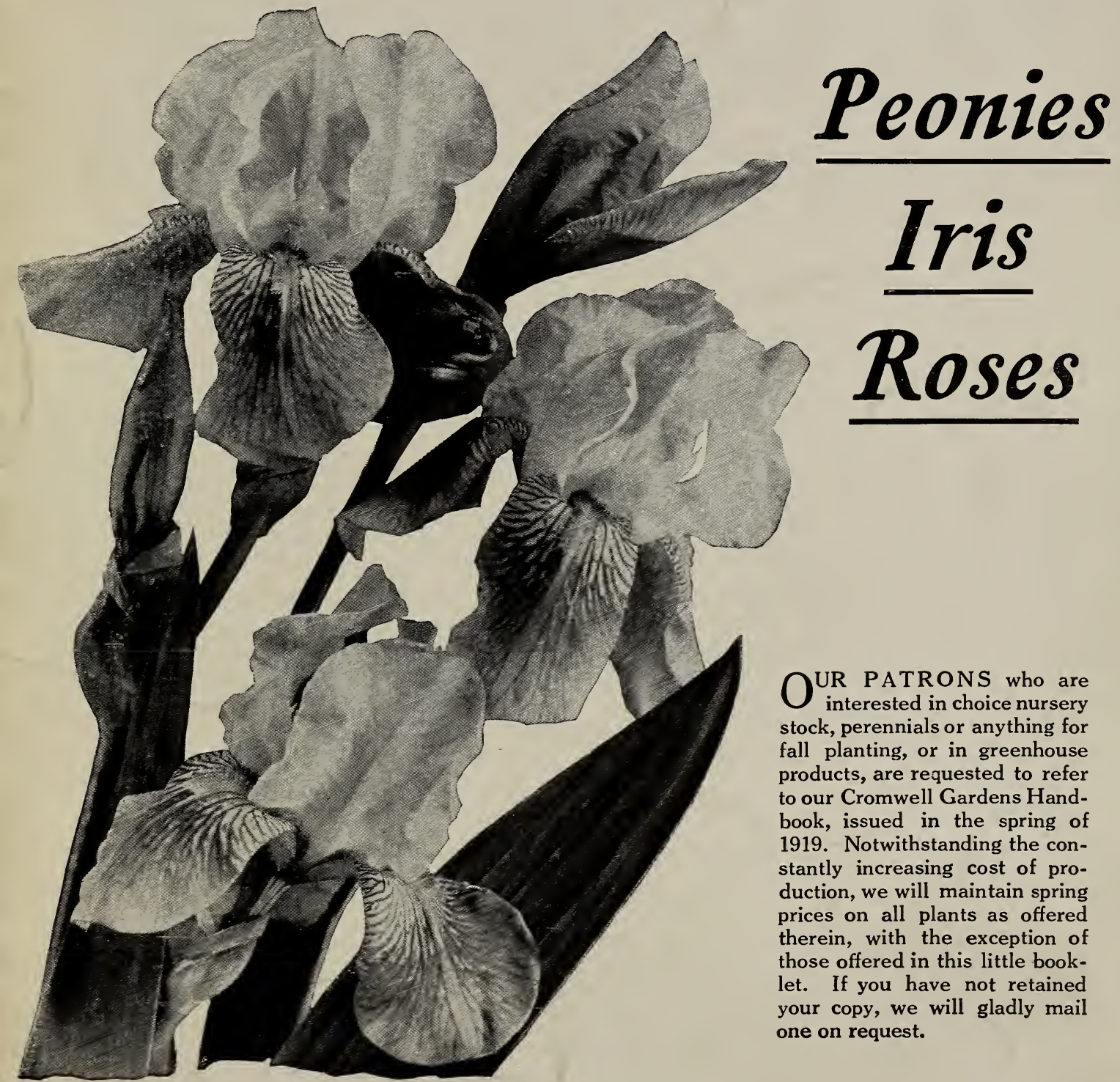

Roses

OUR PATRONS who are interested in choice nursery stock, perennials or anything for fall planting, or in greenhouse products, are requested to refer to our Cromwell Gardens Handbook, issued in the spring of 1919. Notwithstanding the constantly increasing cost of production, we will maintain spring prices on all plants as offered therein, with the exception of those offered in this little booklet. If you have not retained your copy, we will gladly mail one on request.

\section{CROMWELL GARDENS}

A. N. PIERSON, Inc. * Cromwell, Conn. 


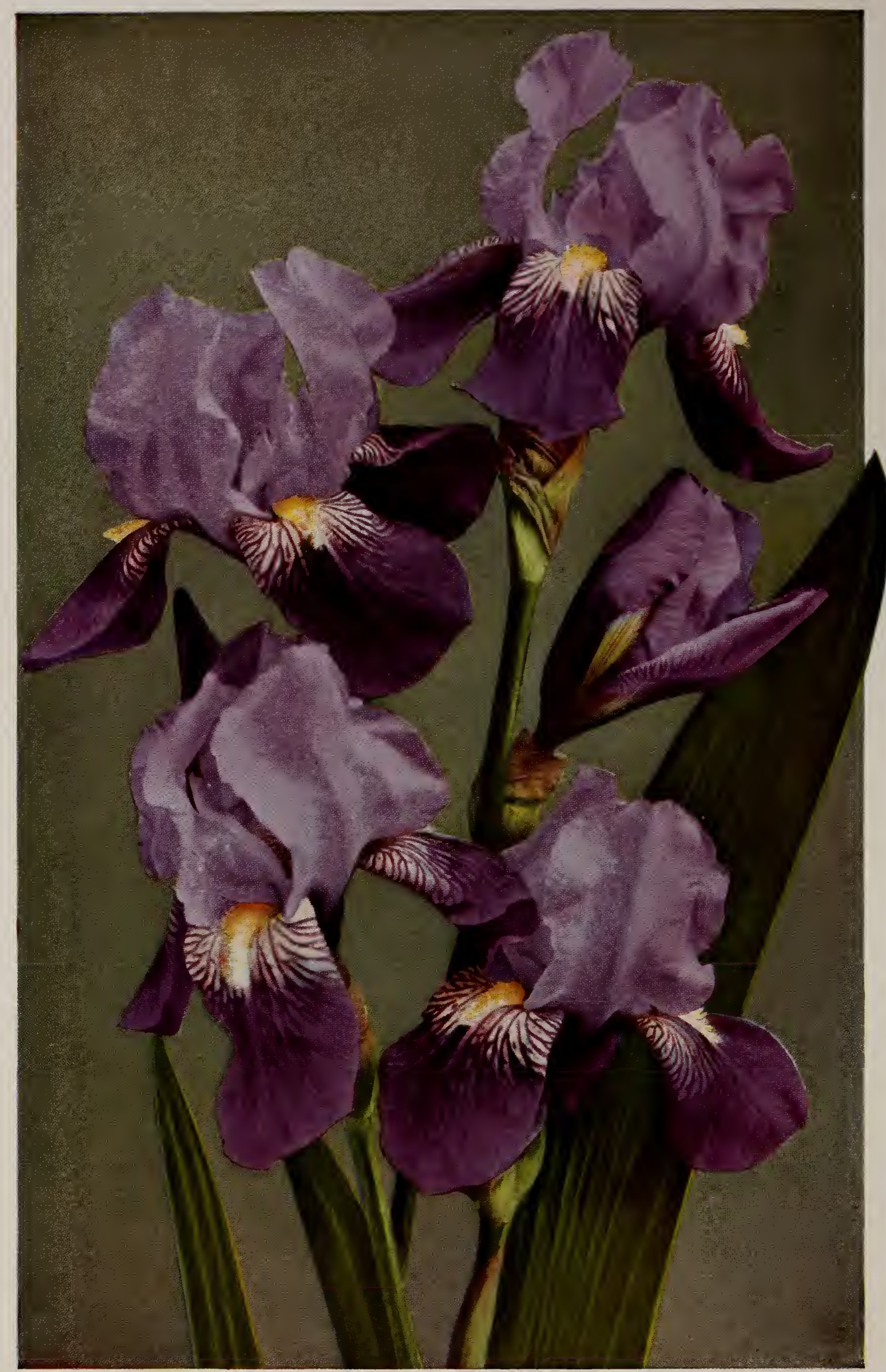

Kharput Fleur-de-Lis (see page 9) 


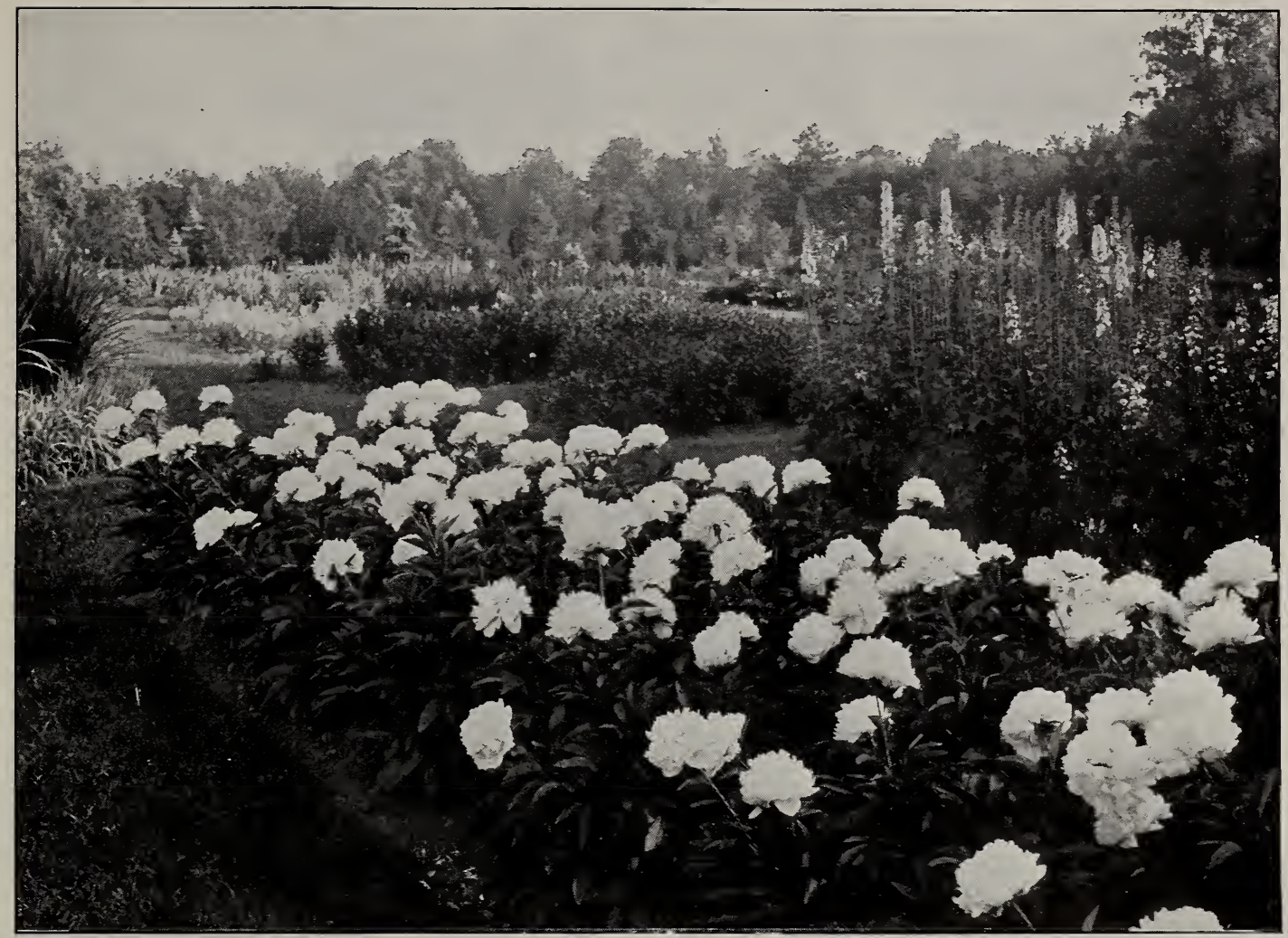

Border of Festiva maxima Peonies (see page 5)

\section{HERBACEOUS PEONIES}

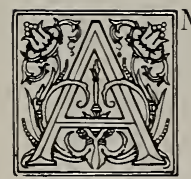

MONG hardy flowering plants there is none which, year after year, will give so great an amount of pleasure and satisfaction, with so little care, as the herbaceous Peony. Once planted, it remains undisturbed for years, each season increasing in size and wealth of bloom.

The best time for planting Peonies is in early September, but they can be planted in perfect safety until the end of October, or in early spring. Early fall planting, however, gives the best results. A deep, rich, well-manured soil should be provided, using thoroughly decayed manure. Set the roots so that the crowns will not be more than 2 or 3 inches from the surface when the soil is firmed. As the Peony, when established, is a robust grower, at least 3 feet of space should be allowed each plant.

For several years we have been carefully assembling a collection of choice Peonies, trying out newer sorts and discarding kinds that did not prove of reaI merit. AII of the Peonies offered have been grown in our nurseries from three to six years, have flowered, and proven true to name.

\section{EXPLANATION OF TYPES:}

Semi-double. Kinds with several rows of wide petals and a center of stamens and partially transformed petaloids.

Crown. Wide petals developed in the center of the flower, forming a high crown, the narrow shorter petals forming a collar around it.

Bomb. The next step toward doubling; wide petaloids and absence of anthers; center petals are nearly uniform throughout the center of the bloom and no collar or crown is evident.

Semi-rose. Loosely built flowers in which the petals are uniformly wide and which show occasional pollen-bearing stamens.

Rose. The familiar type of the fully double bloom; stamens transformed into wide petalcids, similar to the guards, forming a true rose-shaped flower.

\section{SIZES}

The clumps offered as two-year size have been grown two years from a one-year, three- to five-eye division, and are actually three-year size. The three- and four-year clumps are sized in proportion. Planted during September or early October, they should flower the following season, but will not, of course, attain their best until the following season.

We do not recommend the one-year division for fall planting, but can supply all varieties offered in this size at a reduction in price of one-third from the two-year size. 


\section{VARIETIES OF HERBACEOUS PEONIES}

\section{Not less than three of one kind at the dozen rate}

Achille. Rose type. A splendid, tall-growing variety, bearing large, compact flowers on erect stems in early midseason. Color, shell-pink, shading to pale lilac, nearly white. Very free and fragrant. Excellent as a cut-flower and most desirable for mass planting. 2-yr., 75 cts. each, \$7.50 per doz.; 3-yr., \$I each, \$ Io per doz.

Agnes Mary Kelway. Crown type. Creamy white collar, guards and crown deep violet-rose. Growth, tall and vigorous. Free flowering and quite fragrant. A fine midseason variety. 2-yr., \$1.25 each, \$1 2 per doz.; 3-yr., \$2 each, \$20 per doz.

Alexandriana. Rose type. A pretty shade of pale violet-rose. Vigorous, upright grower and very free in flowering. Flowers are large, fuII, very double, and fragrant. Early-flowering and desirable for any purpose. 2-yr., 75 cts. each, $\$ 7.50$ per doz.; 3-yr., \$1.25 each, \$1 2 per doz.

Alexandre Dumas (syn. Rosamond). Light violetrose center, chamois-white collar of narrow petals intermingled with broader center petals. Goodsized flowers produced freely in clusters during midseason. Medium in growth and very fragrant. Specially desirable for cutting purposes. 2-yr., 75 cts. each, \$7.50 per doz.; 3-yr., \$1.25 each, \$1 2 per doz.

Albatre. Rose type. This is the Peony par excellence among aII white varieties, and one that should be in every collection. As a garden variety, for mass planting or Iandscape effect, or as a cut-flower, it is beyond criticism. We consider it the Queen of all Peonies in its color. The flower is very large,

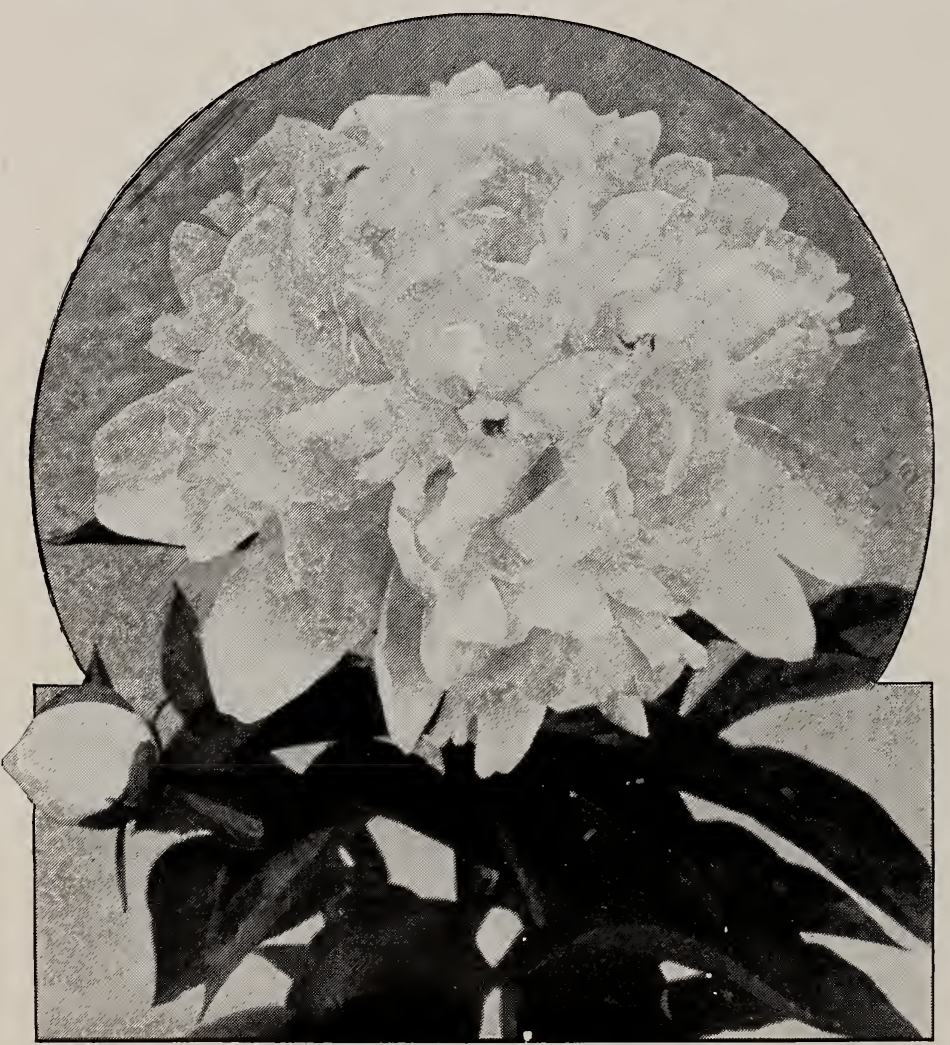

Pæonia Albatre of splendid compact build, and Iovely globular form. The color is a clear milky white, with ivory shadings; the center petals tinged with Iilac and edged with a minute line of carmine. The growth is perfect, robust, and erect, and it is exceptionally free in flowering and very fragrant. Midseason. 2-yr., \$2.50 each, \$20 per doz.; 3-yr., \$3.50 each, $\$ 30$ per doz.

Alice Crousse. Bomb type. A very pretty large flower of loose formation. Outer petals violet-rose, shading to soft salmon or nearly white at the center. A robust grower but medium in height. Very fragrant. Midseason. 2-yr., 75 cts. each, $\$ 7.50$ per doz.; 3-yr., \$1.25 each, \$1 2 per doz.

Albert Crousse. Bomb type. An immense full flower of good form; rose-white in color, lightly and prettily flecked with crimson. Tall, erect habit of growth and very free flowering. A valuable late-flowering kind for any purpose. 2-yr., \$2 each; 3-yr., \$3 each.

Anemonæflora rubra. Anemone. Deep, vivid Tyrian rose, center petals dark crimson. Strong, tall growth and very free, flowering in midseason. 2-yr., 75 cts. each; 3-yr., \$I.50 each.

Antoine Poiteau. Clobular flower of compact form. Color, very light pink or lilac-white, center milky white. Quite fragrant and of good size. A midseason variety of value. 2-yr., \$I each, \$9 per doz.; 3-yr., \$I.50 each, \$I 5 per doz.

Ambroise Verschaffelt. Rose type. A fine Iarge bloom, dark violet-crimson in color, retaining its uniform color well in the sun. Good habit of growth and quite free. 2-yr., $75 \mathrm{c}$. each, \$7.50 per doz.; 3-yr., \$I.25 each, \$1 2 per doz.

Arthemise. Crown type. Light violet-rose toward the center, collar pale pink-a very pretty combination. Strong and erect in growth; fragrant and very free, flowering in midseason. A very desirable kind. 2-yr., \$I each, \$I0 per doz.; 3-yr., \$I.50 each, \$I 5 per doz.

Asa Gray. Semi-rose type. A very distinct and desirable variety. Very Iarge, pale Iilac flowers, sprinkled with minute dots of deeper lilac, flowering late in the season. Growth and habit medium. Very fragrant. A choice Peony that should be in every collection. 2-yr., \$r.50 each, \$I 5 per doz.; 3-yr., \$2.50 each, \$25 per doz.

Alba plena. Bomb type. Pure white flowers, tinged light yellow toward the petal-base. Fragrant. Flowers of good size, carried on strong stems. 2-yr., 75 cts. each, \$7.50 per doz.; 3-yr., \$I.25 each, \$I 2 per doz.

Baron James de Rothschild. Crown type. Pale lilac-rose, intermingled with cream. Mediumsized flowers, but very free and fragrant. Vigorous growth. 2-yr., \$I.25 each, \$I2 per doz.; 3-yr., \$2 each, \$20 per doz. 
Beranger. Rose type. A rather compact flower of good form, clear violet-rose in color. Erect, tall habit of growth, flowering very late. A very desirable late variety. 2-yr., \$1.50 each; 3yr., \$2 each.

Canari. Bomb type. Fine globular flowers of medium size. Guards white, tinted pale pink, center amber, changing to white; carpels and stigmas pink. Good habit and fragrant. 2-yr., \$I.25 each, \$I 2 per doz.; 3-yr., \$2 each, \$20 per doz.

Candidissima. Rose type. Large, double, pure white bloom with sulphur center. Erect, vigorous growth and very free in flowering. Pleasant odor. Early. 2-yr., 75 cts. each; 3-yr., \$I.25 each.

Carnea elegans. Rose type. Medium-sized, flat, compact flowers, hydrangea-pink in color, with red stigmas. Medium growth and very free. A good midseason variety when established. 2-yr., \$I.25 each, \$1 2 per doz.; 3-yr., \$2 each, \$2O per doz.

Couronne d'Or. Semi-rose type. White, with a ring of showy yellow stamens around a center tuft of carmine-tipped petals. Medium height. 2-yr., \$I.25 each, \$1 2 per doz.; 3-yr., \$2 each, \$20 per doz.

Dr. Caillot. Semi-rose type. A very Iargeflowering variety, brilliant, dark Tyrian rose in color. Free, fragrant, and one of the showiest midseason varieties. 2-yr., \$I.25 each; 3-yr., \$2 each.

Duchesse de Nemours. Pure white crown with a sulphur-white coIlar, entirely free from markings. Robust grower; medium height. 2-yr., 75 cts each, $\$ 7.50$ per doz.; 3-yr., \$I.25 each, \$I 2 per doz.

Edulis superba. Large, loose, flat crown. A splendid shade of bright mauve-pink, narrow petals at the collar shaded lilac. Early-blooming and of strong, upright growth. One of the best kinds for cutting and a satisfactory Peony for any purpose. 2-yr., 75 cts. each, \$7.50 per doz.; 3-yr., \$1.25 each, $\$ 12$ per doz.

Eugene Verdier. Rose type. Pale hydrangea-pink, outer petals Iilac-white. Dwarf but erect in growth, carrying large flowers on strong stems. Very free, fragrant, and late in flowering. Splendid for cutting or massing. 2-yr., \$2 each; 3-yr., \$3 each.

Faust. A medium-sized flower of globular crown form. Guard petals and crown hydrangea-pink, crown tipped carmine, narrow sulphur-white colIar petals. Medium in habit. 2-yr., $75 \mathrm{cts}$. each, \$7.50 per doz.; 3-yr., \$1 each, \$IO per doz.

Felix Crousse. Bomb type. One of the very best in the red section. Fine, large, globular flowers, brilliant red in color. Strong, vigorous growth; medium in height and very free. Fine as a cutflower or for garden effect. 2-yr., \$I.25 each, \$12 per doz.; 3-yr., \$2 each, \$20 per doz.

Festiva maxima. Rose type. Conceded to be the most popular of all the Peonies. Very Iarge, clear white flowers, prominently flecked crimson, the outer petals sometimes tinged lilac-white on opening. Very tall and erect and equally useful for massing or cutting. 2-yr., \$I each, \$IO per doz.; 3-yr., \$1.50 each, \$I 5 per doz.; 4-yr., \$2 each.

General Bertrand. Bomb type. A large, compact flower of fine, globular form. In color it is an even shade of solferino-red, center petals tipped silver. Strong, upright habit of growth. A very good early variety. 2-yr., \$1.25 each; 3-yr., \$2 each.

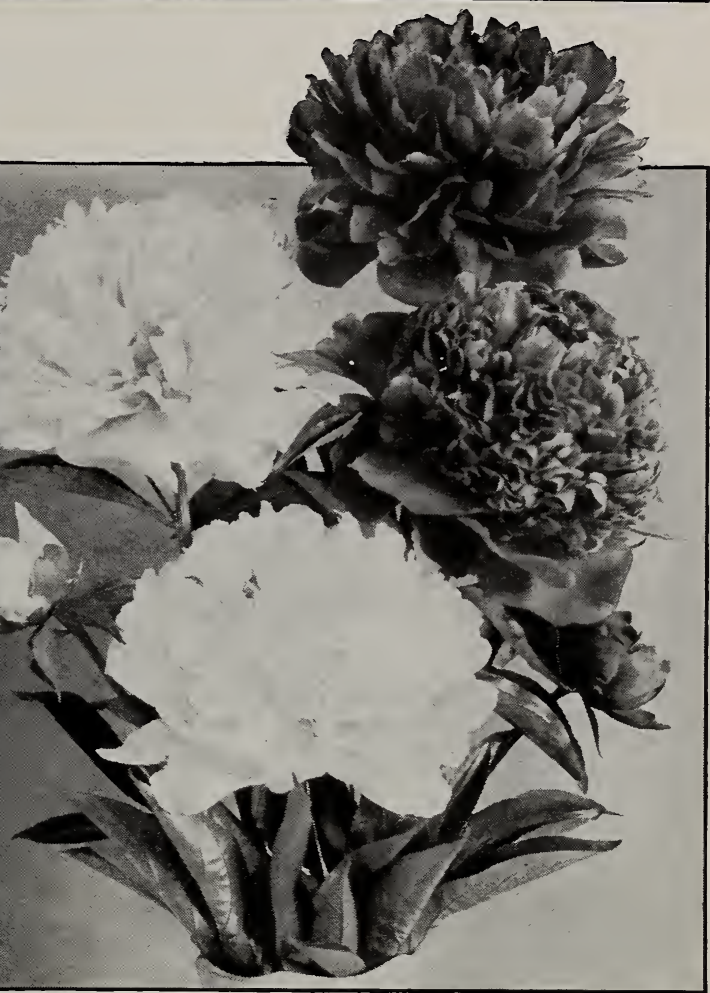

Felix Crousse and Couronne d'Or Peonies

Grandiflora rubra (syn. Marechal Vaillant). Rose type. Very Iarge, compact flower of globular form, mauve-pink in color. TaII, heavy, and somewhat coarse in growth. A good late variety. 2-yr., $\$ 1.25$ each; 3-yr., \$2 each.

Jeanne d'Arc. Bomb type. Large, globular flowers produced very freely. Guards and center pale lilacrose; collar sulphur-white. A strong grower of medium height, much resembling GoIden Harvest. Midseason. 2-yr., \$I each; 3-yr., \$I.50 each.

La Tulipe. Rose type. A very large, flat flower; Iilac-white, outer petals marked or striped crimson, a rather unique effect. Very free, vigorous, and fragrant. A good midseason kind. 2-yr., \$1.25 ea.; 3-yr., \$2 each.

Louis Van Houtte. A fine late Peony of the semirose type. Deep carmine-rose in color, tipped silver, with fiery reflex. Very vivid coloring. Medium in growth and very free. 2-yr., 75 cts. each, \$7.50 per doz.; 3-yr., \$1.25 each, \$12 per doz.

Marguerite Gerard. Semi-rose type. Pale hydrangea-pink, shading to nearly white, center marked or flecked dark carmine. The flower is large and of compact form. Growth strong; medium height. Free-blooming; Iate. 2-yr., \$3 each.

Marie Lemoine. Rose type. Enormous flowers of fine, compact build. Color, pure white with creamwhite center, occasionally tipped carmine. The flowers are carried well above the foliage on extrastrong stems. Pleasant odor. One of the finest Iate-flowering varieties for mass or garden planting and splendid for cutting. 2-yr., \$I each, \$IO per doz.; 3-yr., \$I.5O each, \$I 5 per doz.

Marie Crousse. Bomb type. A fine, Iarge flower of loose, globular formation. Color, an even shade of pale lilac-rose. TaII, erect habit of growth and very free. An extra-choice midseason variety. 2-yr., \$5 each; 3-yr., \$7.50 each. 


\section{VARIETIES OF HERBACEOUS PEONIES, continued}

Mme. Breon. Bomb type. White, with shell-pink guards. Medium-sized flowers of good form. Growth tall and vigorous. Very free and early. A good Peony. 2-yr., \$I each, \$Io per doz.; 3-yr., \$1.50 each, \$I 5 per doz.

Mme. Calot. Rose type. Pale hydrangea-pink, center shaded darker, tinted sulphur in collar. Flowers are very large and are freely produced. Strong, vigorous habit. Early flowering. 2-yr., \$I each, \$Io per doz.; 3-yr., \$I.50 each, \$I 5 per doz.

Mme. Crousse. Crown type. Pure white, center flecked crimson. Well-formed flowers of medium size. Vigorous growth and very free flowering. One of the best midseason varieties. 2-yr., \$1.25 each, \$12 per doz.; 3-yr., \$2 each, \$20 per doz.

Mme. Ducel. Bomb type. Light mauve-rose, with silvery reflex. Large flowers of splendid globular form. Vigorous in growth, fragrant, and very free. A very choice variety. 2-yr., \$1.25 each; 3-yr., \$2 each.

Mme. de Verneville. A large, fuII flower of bomb type; pure white, with carmine-tipped central petals. A splendid early-flowering variety of pleasant odor; extra free. 2-yr., \$I each, \$Io per doz.; 3-yr., \$I.50 each, \$I 5 per doz.

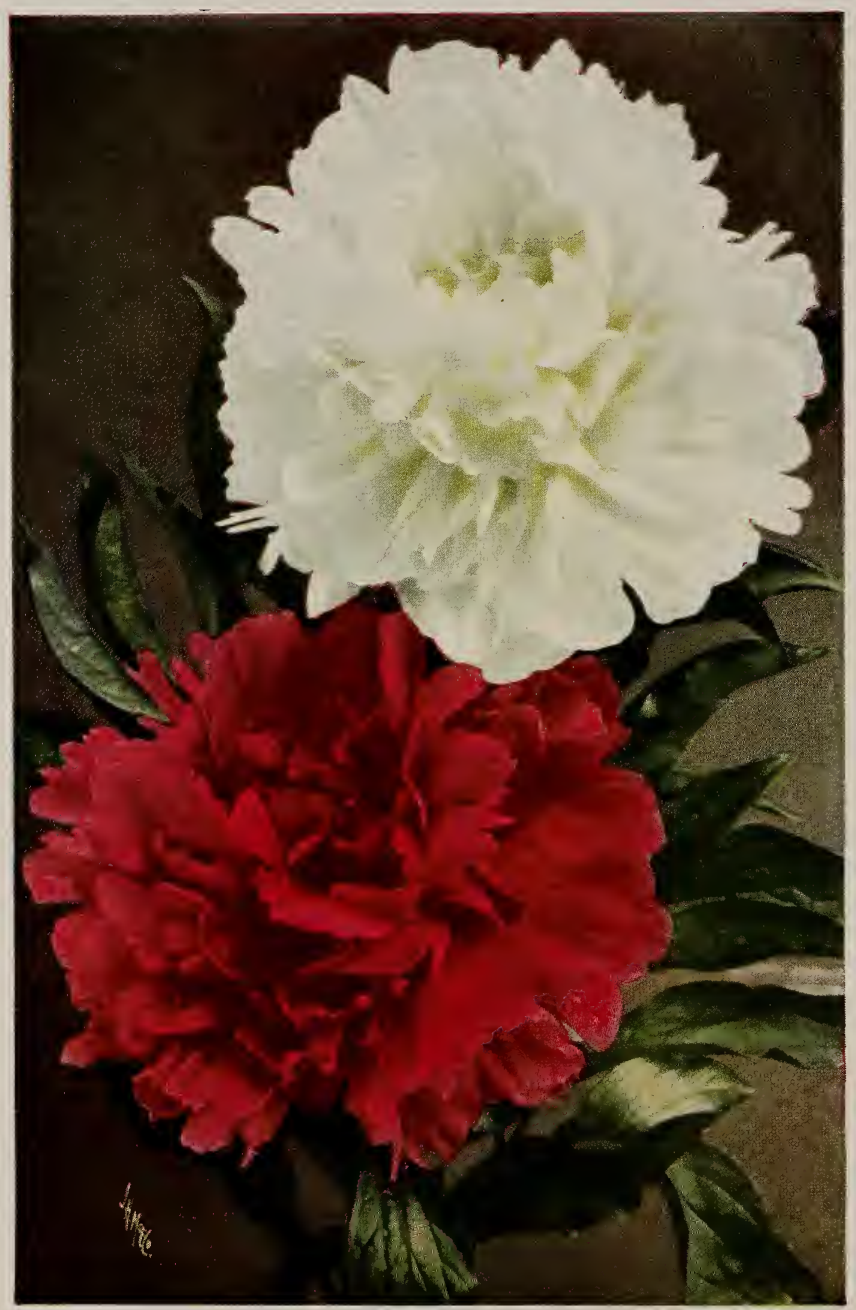

Solfatare and Prince Imperial Peonies
Mme. Forel. Rose type. A very large, imbricated flower of compact form, violet-rose in color, tipped silver toward the center; growth good. A very desirable late variety. 2-yr., \$1.50 each, \$I 5 per doz.; 3-yr. \$2 each, \$20 per doz.

Mme. Jules Elie. Crown type. Guards violet-rose, collar cream-white, center marked crimson. Large flowers of nice globular form. Erect, vigorous growth. Midseason. 2-yr., \$1.25 each, \$ 2 per doz.; 3-yr., \$2 each, \$20 per doz.

Mons. Jules Elie. Bomb type. Pale lilac-rose, collar lighter, shaded amber-yellow at base. Early. Large; good form; vigorous growth. 2-yr., \$2 each.

Nobilissima. Semi-rose type. Large, flat flowers, deep violet-rose in color. Erect, strong growth, very free. A distinct and desirable midseason variety. 2-yr., \$1.50 each; 3-yr., \$2.50 each.

Prince Imperial. Semi-rose type. Amaranth-red. Flower large and of Ioose formation carried on extra-good stems; strong and vigorous. A good midseason garden variety. 2-yr., \$I ea.; 3-yr., \$2 ea.

Queen's Perfection. Crown type. Lilac-white, with sulphur-white center. Very free; vigorous in growth. Early. 2-yr., 75c. each; 3-yr., \$1.25 each.

Queen Victoria (syn. Whitleyi). Bomb type. Loose flower of globular form. Color, milky white, flecked with crimson. Freeflowering and fragrant. An old midseason favorite. 2-yr., 75c. ea., \$7.50 per doz.; 3-yr., \$I each, \$Io per doz.

Rubra triumphans. Large, loose, semidouble flowers of vivid crimson. A vigorous, healthy grower, flowering in midseason. 2-yr., 75 cts. each, \$7.50 per doz.; 3-yr., \$I.25 each, \$I 2 per doz. Solfatare. Bomb type. A very distinct and desirable Peony. Sulphur-white, with milk-white guard-petals. Medium growth and good stems. Fragrant. Midseason. 2-yr., \$I each; 3-yr., \$I.50 ea.

Triomphe de l'Exposition de Lille. Semi-rose type. Pale hydrangea-pink, splashed with violet tints, guard petals fading to nearly white. Very large, compact bloom, and a free-flowering, strong, vigorous grower. Midseason. Useful for cutting or mass planting. 2-yr., \$1.25 each; 3-yr., \$2 each.

\section{PEONIES FOR MASSING Special Offer. We have a Iarge special block of mixed,} or rather unidentified varieties, but kinds that are of real value for mass planting, or for those who grow Peonies for the flower itself and are not concerned with names. They can be supplied in white, pink, or red colors, or in mixed kinds, in very heavy four- and five-year-old clumps. so cts. each, \$5 per doz.

\section{PAEONIA OFFICINALIS}

This old-fashioned type comes into bloom some two weeks before the other varieties. The flowers are Iarge, full, very fragrant, and decidedly attractive in the garden or old-fashioned border.

Alba. Blush-white.

Rubra. Deep, dark crimson.

Rosea. Soft, bright rose.

75 cts. each, $\$ 7.50$ per doz. 


\section{FLEUR-DE-LIS (GERMAN IRIS)}

$\mathrm{T}$

HE almost unlimited range of colors and attractive combinations displayed in this group surely warrant the rather apt description, "the poor man's orchid." Assuredly, it is the orchid of the garden since the addition of recent varieties with their cattleya shades and exquisite markings. Doing weIl in any reasonably good soil and location, their culture is simple. When planting, avoid fresh manure and plant merely deep enough to cover the roots properly. A mulch of well-decayed manure should be applied in early winter. Once established, the Iris is practically permanent, and as they increase rapidly by division, it is advisable to plant only choice kinds even if the planting must be limited, and depend upon the increase for further planting.

Many hundreds of varieties have been tried out in our gardens; some are offered here, but the majority have been discarded as undesirable or because they are not sufficiently distinct in character. AII of the kinds Iisted here are useful and desirable, but we particularly recommend a selection of the newer kinds to those that prefer the more choice garden subjects.

\section{NEW AND RARE VARIETIES}

BLUE BOY. A hybrid variety of prolific and vigorous growth. The color is a distinct shade of blue, with a blue beard; velvety purple falls. 5oc. ea., \$5 per doz.

BLUE JAY. Standards clear, light blue; faIls, intense dark blue. Splendid, vigorous habit of growth. 50c. ea., \$5 per doz.

CANDELABRA. Standards Iavender blue, dotted and reticulated dark bue; falls deep indigo-blue, with white markings. The flowers are large and are carried on strong stems. Growth vigorous. Very distinct and desirable. 75 cts. ea., $\$ 7.50$ per doz.

CAPRICE. Standards rosy red; falls shading to a deeper red. Dwarf in habit and very free. 35 cts. each, $\$ 3.50$ per doz.

CATERINA. One of the famous Foster seedlings, producing massive Iavender flowers on stems fully 4 feet in height; similar to Pallida dalmatica but larger and more prominently veined at the throat. 75 cts. each, $\$ 7.50$ per doz.

DOROTHEA. Standards milky white, flushed blue; falls Iavender-white with deeper blue markings. Very dwarf. 35 cts. each, \$3.50 per doz.

HALFDAN. Standards and falls creamy white. Flowers Iarge; dwarf. 35 cts. each, \$3.50 per doz.

IROQUOIS. Standards smoky Iavender, dotted brown; falls dark maroon, reticulated white at the base. Vigorous and erect in growth and very distinct. 50 cts. each, \$5 per doz.

ISOLINE. Very Iarge flower of splendid form and unusual texture; standards silvery lilac, shading to Iilac-pink; falls mauve with orange beard. A very distinct and beautifuI Iris. \$I each.

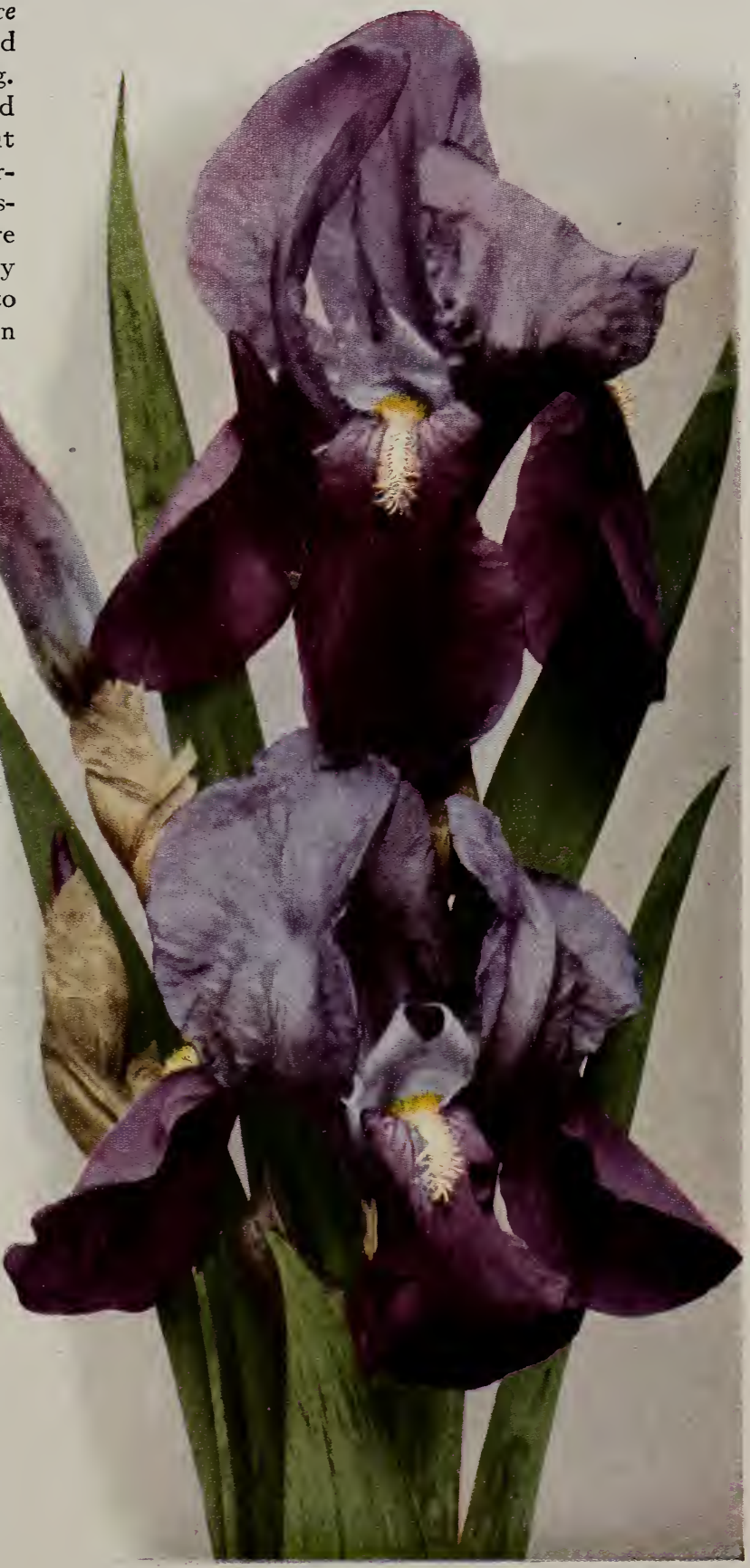

Iris, Purple King (see page 10) 


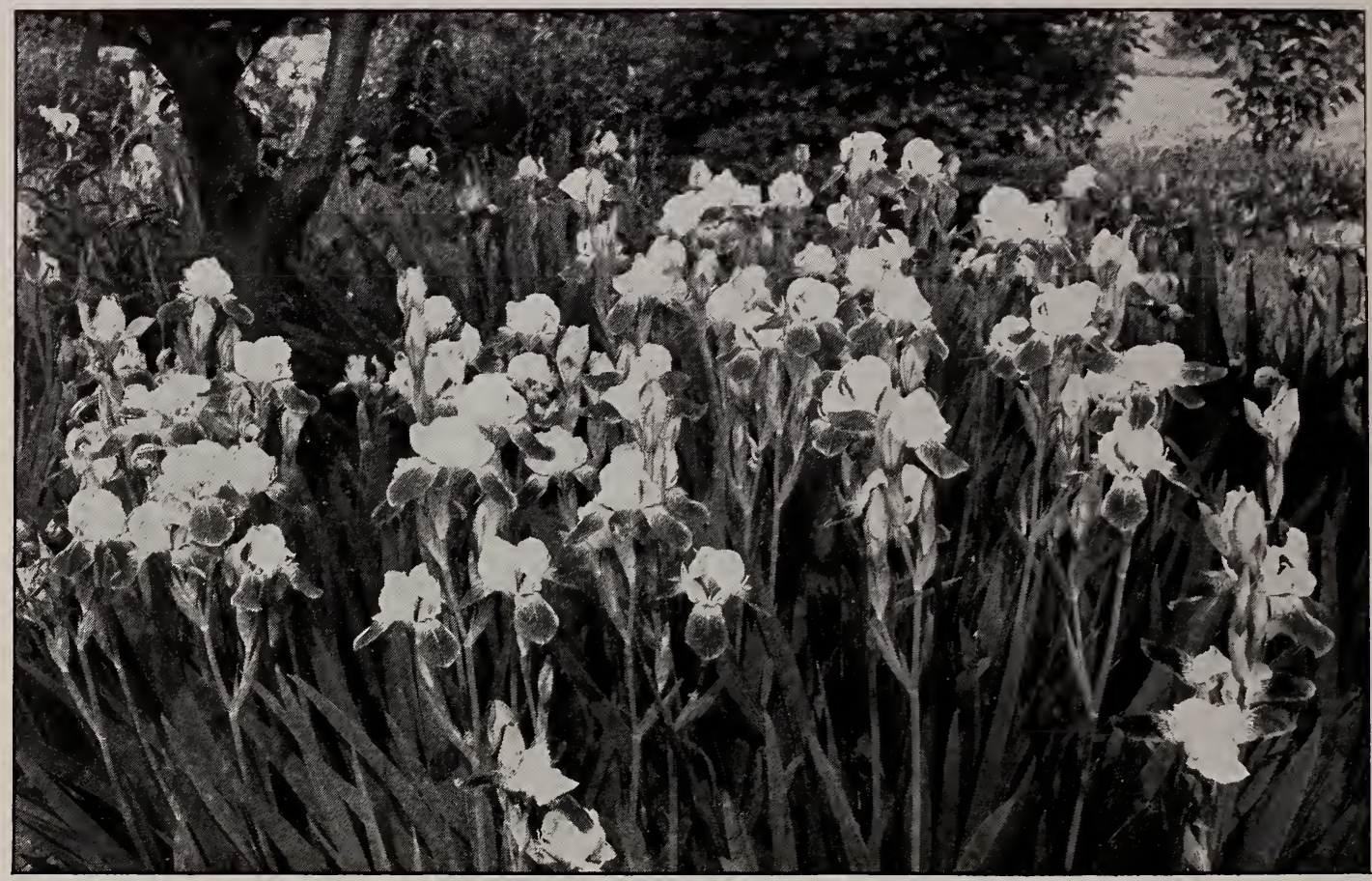

Iris Maori King thriving in partial shade

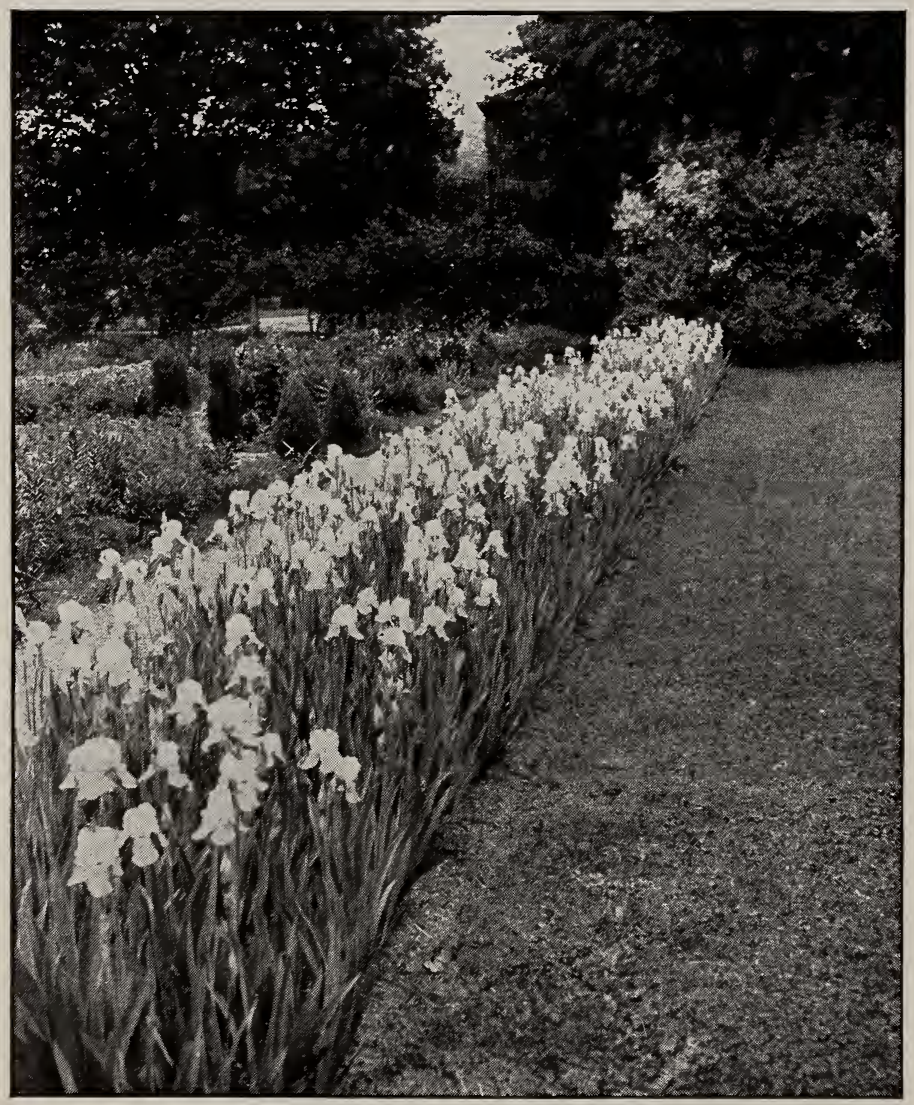

Border of Iris florentina alba
NEW AND RARE IRIS, continued JUNIATA. (PaII.) Large, fragrant, deep-blue flowers, larger and darker than DaImatica 50c. each.

LONTE. Rich bronze standards and purple and copper-shaded falls. 50 cts. each, \$5 per doz.

MONSIGNOR. Standards rich, satiny violet; falls overlaid rich purple-crimson, with lighter margin. Fine large flower. 75 cts. each, $\$ 7.50$ per doz.

MRS. G. REUTHE. Standards white, veined blue-gray; falls white, frilled soft blue. Very large and handsome. 35 cts. each, $\$ 3.50$ per doz.

QUAKER LADY. Smoky lavender standards, shaded with pretty yellow tones; falls bright ageratumblue and bronzy gold; stigmas and beard yellow. A fine addition. 75 cts. each, $\$ 7.50$ per doz.

ROSE UNIQUE. Bright, violetrose closely approaching the muchdesired true pink Iris. A splendid variety for color-effect in the garden. 75 cts. each, $\$ 7.50$ per doz.

TAMERLANE. Deep violet-purple falls, with paler standards. 35 cts. each, \$3.50 per doz.

TECUMSEH. Standards cloudy buff; falls violet, bordered yellow; very pretty. $50 \mathrm{cts}$. each.

Nothing can supply a richer color effect than the Irises; they have been truly called the "Poor Man's Orchids." 


\section{Cromwell, Conn. $\quad 9 \quad$ FLEUR-DE-LIS}

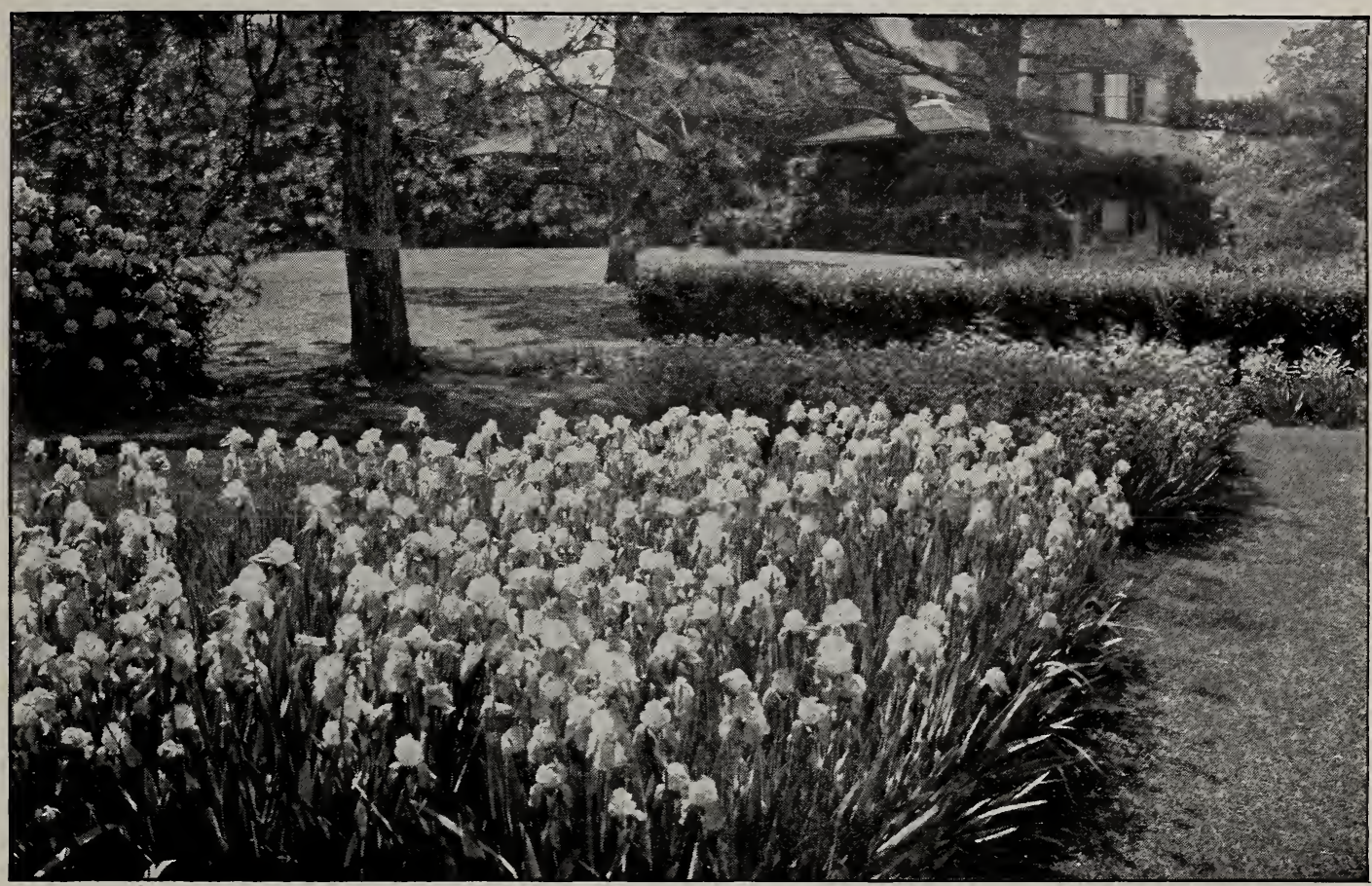

Iris planted in beds are very attractive

\section{CHOICE IRIS}

15 cts. each, $\$ 1.50$ per doz., $\$ 10$ per 100 , except when noted

Albert Victor. (PaII.) Soft blue standards; faIIs beautifuI soft Iavender. 25 cts. each, $\$ 2.50$ per doz.

Amas. A Iarge-flowered variety from Asia Minor. Standards rich blue; falls violet. $25 \mathrm{c}$. ea., \$2.50 per doz.

Aurea. Very Iarge, rich chrome-yellow flowers. Strong and robust in growth; the finest pure yellow. $25 \mathrm{cts}$. each, \$2.50 per doz.

Florentina alba. Soft gray, faintly flushed lavender; creamy white in effect. One of the first to flower; fragrant and splendid either for cutting or mass effect.

Her Majesty. Standards pale pink; falls deep rose, shading to crimson. A very lovely variety. 35 cts. each, \$3.50 per doz.

Honorabilis. Standards golden yellow; falls rich mahogany. Very effective.

Kharput. Rich violet-blue standards; faIIs rich purple. Flowers Iarge, carried erect on strong stems. Very handsome and effective.

King of Iris (Iris King). This new Iris, the result of crossing Maori King with Pallida daImatica, represents a striking advance on all Iris of its color. Standards clear yellow; falls very Iarge, deep satiny brown, with a broad border of golden yellow. Nicely-formed, Iarge flowers and vigorous in growth. 50 cts. each, $\$ 5$ per doz.

L'Innocence. Deep Iavender standards; white falls. Very good.

Lohengrin. Very Iarge, wide-petaled flowers; a uniform and lovely shade of soft cattleya-rose. One of the prettiest varieties yet introduced. $50 \mathrm{cts}$. each, \$5 per doz.

Maori King. Rich golden yellow standards; velvetycrimson falls, with gold margins.

Mme. Chereau. Standards and falls pure white, daintily frilled with a border of clear blue. A lovely variety. 25 cts. each, $\$ 250$ per doz.

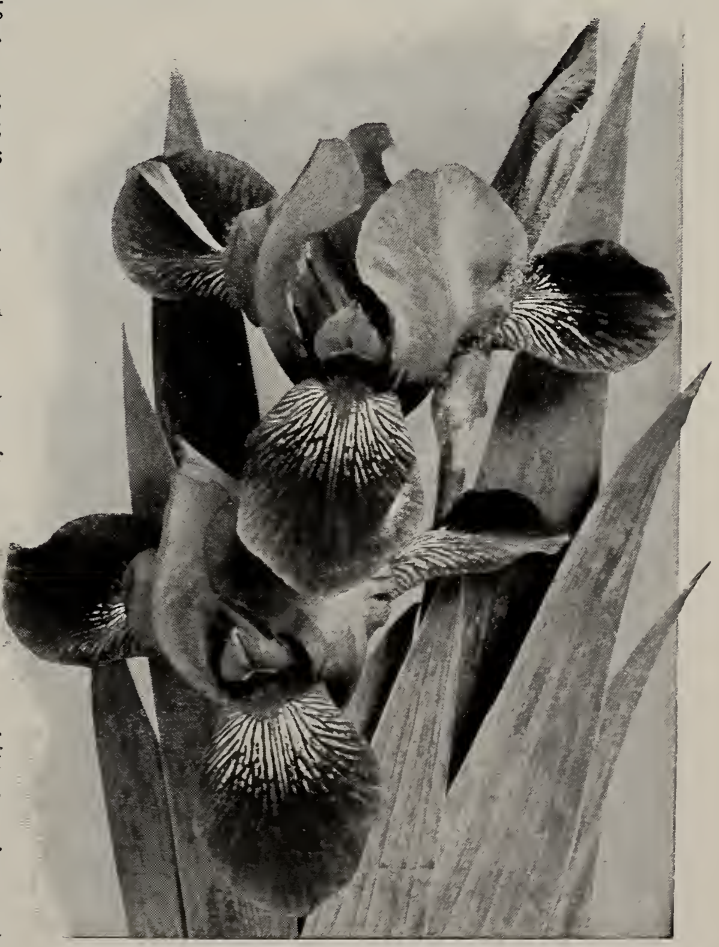

Iris Honorabilis 


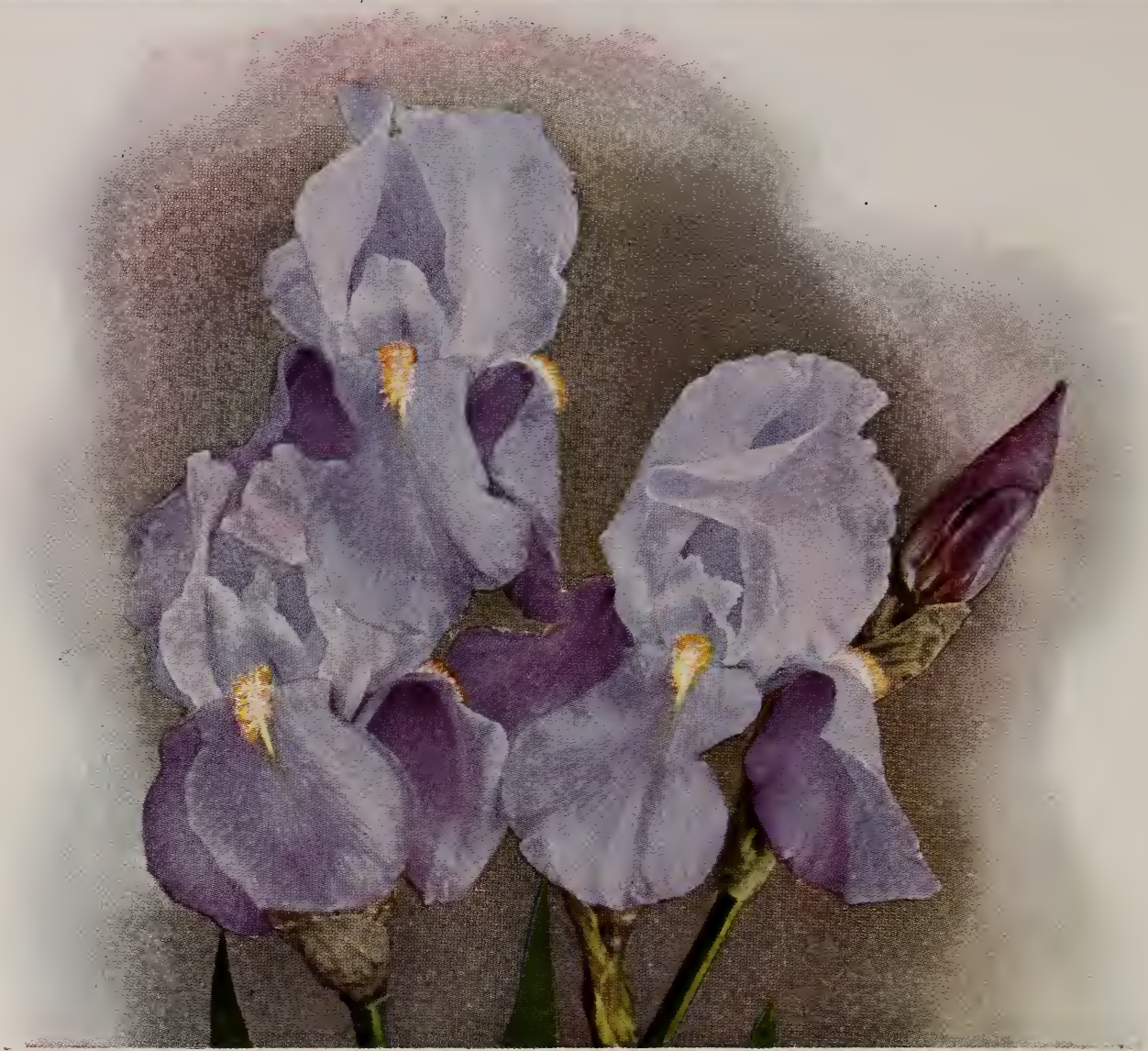

Iris pallida dalmatica

\section{CHOICE IRIS, continued}

Mandraliscæ. Deep Iavender-purple. Vigorous growth and splendid flower. An early variety. 25 cts. each, \$2.50 per doz.

Mrs. H. Darwin. Clear white standards; falls slightly veined violet at the base. Very free and beautiful. 25 cts. each, $\$ \mathbf{2 . 5 0}$ per doz.

Mrs. Neubronner. Very deep golden yellow. A gem for cutting or for massing. 25 cts. each, $\$ 2.50$ per doz.

Othello. Standards intense, rich blue; falls dark velvety purple. Tall-growing and good for cutting or massing. 25 cts. each, $\$ 2.50$ per doz.

Pallida dalmatica. One of the finest varieties. Strong, vigorous habit; exceptionally Iarge, fragrant flowers. Standards Iavender; falls lavender, tinged purple. A variety of unusual merit. 25 cts. each, $\$ 2.50$ per doz
Princess Victoria Louise. Standards pure sulphur-yellow; falls rich violet-plum with creamy margin. Very distinct. 35 cts. each, $\$ 3.50$ per doz.

Purple King. Deep, solid purple. One of the most effective in this color. 25 cts. each, $\$ 2.50$ per doz.

Queen of May. Beautiful soft rose-lilac.

Sambucina. A very fragrant variety, the odor of which is not unlike the elder, Sambucus, hence the name. Standards coppery rose; falls bright rosy purple, with an orange crest. A tall-growing, showy species. 25 cts. each, $\$ 2.50$ per doz.

Spectabilis. Light and deep violet-purple. A very free-flowering variety and most Iovely color combination, effective for massing.

Violacea grandiflora. Standards clear lavender; falls violet-blue. A beautiful variety. $25 \mathrm{cts}$. each, $\$ 2.50$ per doz.

\section{IRIS OF OTHER TYPES}

Orientalis, Snow Queen. An exquisite new Iris, similar to but flowering earlier than the other varieties. Pure snow-white; graceful foliage. 25 cts. each, \$2.50 per doz.

Pseudacorus. Water Flag. A semi-aquatic variety, useful for marsh or water's-edge planting. Yellow, shaded orange. May and June. 3 feet. I 5 cts. each, \$1.50 per doz.
Pumila. A dwarf-growing type suitable for the rock-garden, flowering in late spring; white, yellow, and bright blue. 20 cts. each, $\$ 2$ per doz.

Sibirica. A tall, showy variety with bright purplish blue flowers and tall, grassy foliage. One of the best for cutting and invaluable for massing in the garden or for waterside planting. I 5 cts. each, $\$$ I.50 per doz. 


\section{JAPANESE IRIS (Iris Kaempferi)}

There is no hardy garden subject that can approach the beauty of its delicate orchid-like blossoms. Flowering, as it does, during late June and July, a period when the hardy garden has passed its early summer glory, these magnificent flowers are particularly weIcome, either for garden decoration or for cutting purposes. Cut in the bud stage, just as the first petals commence to unfold, and placed in water, the flowers will expand and keep remarkably well.

The Japanese Iris succeeds weIl in ordinary garden soil, but does best in a rich, moist loam. It should have a location that drains well during winter. In a dry location good results are obtained by countersinking the beds slightly.

Prices, except where noted, 30 cts. each, $\$ 3$ per doz., $\$ 20$ per 100

Gekka-no-nami (Waves under Moonlight). Earliest to bloom, and the choicest white; very free. Glistening white, with creamy white stigmas.

Gold Bound. A fine, double, pure white with goldbanded center.

Hanna-no-Nishiki (No. 33. Flower Embroidery). Six to eight petals in conical arrangement with weIldeveloped petaloids; the most fully double variety in the collection. Color claret-pink with fine white veins.

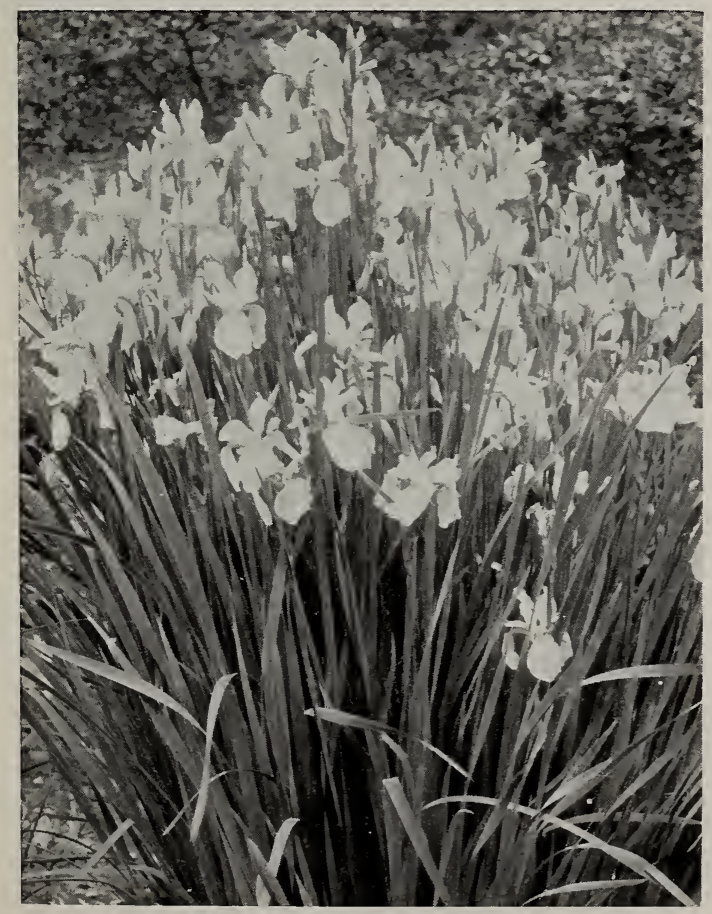

Iris sibirica (see page 10)

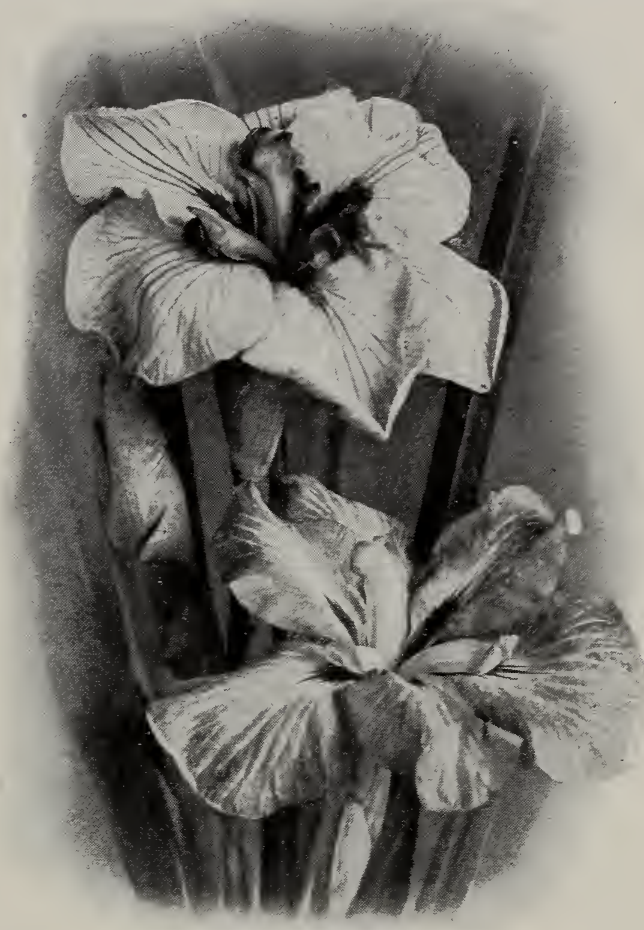

Flowers of Japanese Iris

Momi-yi-no-taki (Maple Waterfall). A choice, double, variegated variety; bright crimson-purple beautifully feathered in white; petaloid stigmas white, purple crested.

Purple and Gold. Enormous double flowers, often Io inches across; early and free blooming; one of the very best varieties. Color rich violet-purple with white petaloids, tipped violet. The conspicuous golden throat extending outward in sharp bluish white rays strongly suggests a bearded wheat head.

Uji-no-Hotaru (No. 42). Deep violet-purple, shaded with blue. Very large six-petaled flowers. One of the finest late kinds.

Wase-Banri (No. 30). White, delicately veined blue; deep blue standards edged white. Three petals.

Yedo-Jiman (No. 2). Deep, royal blue, conspicuous yellow spot with a silvery white halo; dark purple standards and violet-blue petaloids. Vigorous grower; one of the largest and showiest of the three-petaled varieties. $50 \mathrm{cts}$. each, $\$ 5$ per doz.

OUR GENERAL CATALOGUE, containing a profusion of illustrations, lists everything for the home grounds and greenhouse-Evergreen Trees and Shrubs, Flowering Shrubs, Roses, Hardy Perennials, Greenhouse Roses, Chrysanthemums, Greenhouse and Conservatory Plants, Bedding Plants 


\section{GARDEN ROSES FOR FALL PLANTING}

OSES planted at this season immediately develop a strong growth of new roots and are, therefore, well established when the growing season again commences, producing a greater number of flowers and a more vigorous growth than spring-planted stock could be expected to.

Ample protection can be provided by drawing the soil around each plant to a height of 12 to I 5 inches. This should be top-dressed with a generous covering of leaves or litter, but not until after the soil has become thoroughly frozen, the object being to keep the soil frozen rather than to exclude frost.

Climbing Roses may be readily protected by laying the growths on the ground and covering as above. Tree Roses should be carefully bent over until the top can be covered on the ground and staked in this position. The stem, being entirely hardy, requires no covering.

The varieties offered are, with few exceptions, strong 2-year plants. Many varieties not listed here can be supplied for spring planting.

\section{EVERBLOOMING TEA AND HYBRID TEA ROSES}

Price, except where noted, $75 \mathrm{cts}$. each, $\$ 7.50$ per doz. Three of a kind will be supplied at the dozen rate. Varieties marked * can be supplied in strong, 2-yr. plants from pots. Those not marked will be supplied in 2-yr. field-grown plants, ready October 1.

Gruss an Teplitz. Bright scarlet-crimson, with vivid, frery red center; quite hardy and extremely free-flowering.

*Isobel. This 5 -petaled variety we consider a splendid addition to the single-flowering type. Large flowers of rich carmine-red, flushed orange-scarlet, with foint copper shadings, pure yellow center. \$I each, \$9 per doz.

*Jonkheer J. L. Mock. Carmine, changing to imperial pink, with a silvery rose-white reflex.

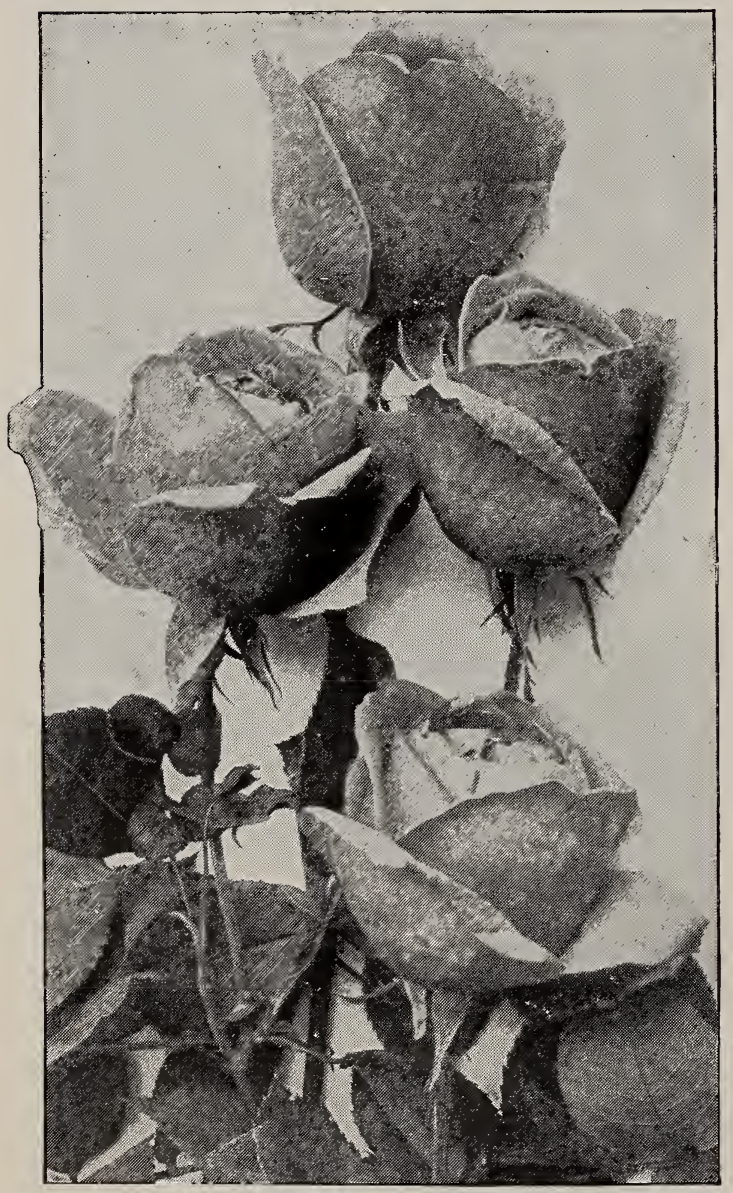

Red Radiance
*Killarney. Color bright, sparkling pink, shading to white.

Lady Alice Stanley. Deep coral-rose on outside, inside pale flesh, slightly flushed deeper flesh.

* La Tosca. Silvery pink, with deeper pink center. Large, double flowers; free and vigorous.

Mme. Caroline Testout. Satiny rose, with bright center; large, full, globular; very free; fragrant.

*Mrs. Charles Bell. This delightful Rose, introduced by us in 1918 , has proved so satisfactory that it is now being ordered in quantity by those who purchased it last season. It is a lovely shade of soft or shell-pink, on a salmon background; equally beautiful in bud or fuII, open flower. In growth, superior to its parent, Radiance, flowering continually the entire Rose season. One of the best. \$1.25 each, \$1 2 per doz.

* Maman Cochet. Beautiful rose-pink, outer petals splashed bright rose; extra strong in growth.

* Panama. This splendid new Rose is a seedling from the popular Frau Karl Druschki. Unusually vigorous and free-flowering, even more so than its parent; an unusually good variety. Very delicate flesh, shading lighter toward the petal margins. Awarded the American Rose Society's Silver Medal at the Hartford Test-Garden.

*Radiance. An American-bred Rose of so many excellent qualities that it may be considered the best bedding Rose in this color. Bright carminesalmon, mingled with rose, shading to a coppery yellow at the base of the petals.

*Red Radiance. A clear, cerise-red sport of Radiance, introduced by us in 1916, and now recognized as a garden Rose of unusual merit. It has the same free-flowering qualities as its parent, being in bloom continuously during the season. The growth is even more robust and vigorous, carrying the large, well-formed flowers on heavy, erect stems.

*Titania. China Tea. Branching habit of growth with the free-flowering qualities of the China Rose. Coppery crimson in the bud form, opening to deep salmon-red, with clear yellow shadings at the base of the petals. \$I each, \$9 per doz.

*White Killarney. White sport of Killarney, with tinge of pink during hot midsummer days. Strong in growth; free-flowering; very fragrant.

*White Maman Cochet. A pure white sport of Maman Cochet and a counterpart of it, except in color. One of our best white garden Roses.

*William R. Smith. One of the finest garden Roses of American origin. Color creamy white, flushed and suffused with bright rosy pink. 


\section{HYBRID PERPETUAL, OR REMONTANT ROSES}

75 cts. each, $\$ 7.50$ per doz., $\$ 60$ per 100

Alfred Colomb. Bright cherry-red, shaded with crimson; of fine, globular form and very sweet. Anna de Diesbach. Clear, bright carmine-rose; fragrant; free and continuous bloomer; large and finely shaped.

Baroness Rothschild. Pale flesh; very large, fuII; superb in form. A chaste and beautiful Rose.

Baron de Bonstetten (Monsieur Boncenne). VeIvety, blackish crimson; large and full.

Captain Hayward. Bright carmine-crimson; Iargepetaled flowers, opening well; fragrant and free.

Clio. Very delicate flesh-color, center shaded pale pink; large, full and globular.

Fisher Holmes. Rich crimson, shaded scarlet; large, full, and of good form. Very free and showy.

Frau Karl Druschki. Pure white in color, perfect in form, and very free flowering. The best white variety which, although usually listed as a Remontant, has all of the valued characteristics of a Hybrid Tea.

General Jacqueminot. This magnificent variety, known for over a half-century as the "Jack Rose," is entirely too well known to require description. Flaming scarlet.

George Arends. Large, fuIl, delicate rose-pink flowers, deliciously scented. Very free and vigorous.

George Dickson. Velvety black, shaded crimson, veined crimson-maroon; fragrant and of splendid substance and form. Another splendid addition to this class.

Gloire de Chedane Guinoisseau. Brilliant vermilion-red, shaded velvety red; Iarge, fuIl, and perfectly formed. A fine new Rose.

Gloire Lyonnaise. White, shaded light yellow; very large; fuIl flowers of splendid form. Free and distinct.

Heinrich Munch (Pink Druschki). Soft rose-pink; very Iarge, full flower; free and vigorous.

Hugh Dickson. Brilliant crimson, shaded scarlet. A magnificent Rose of good size and excellent form; free and fragrant.
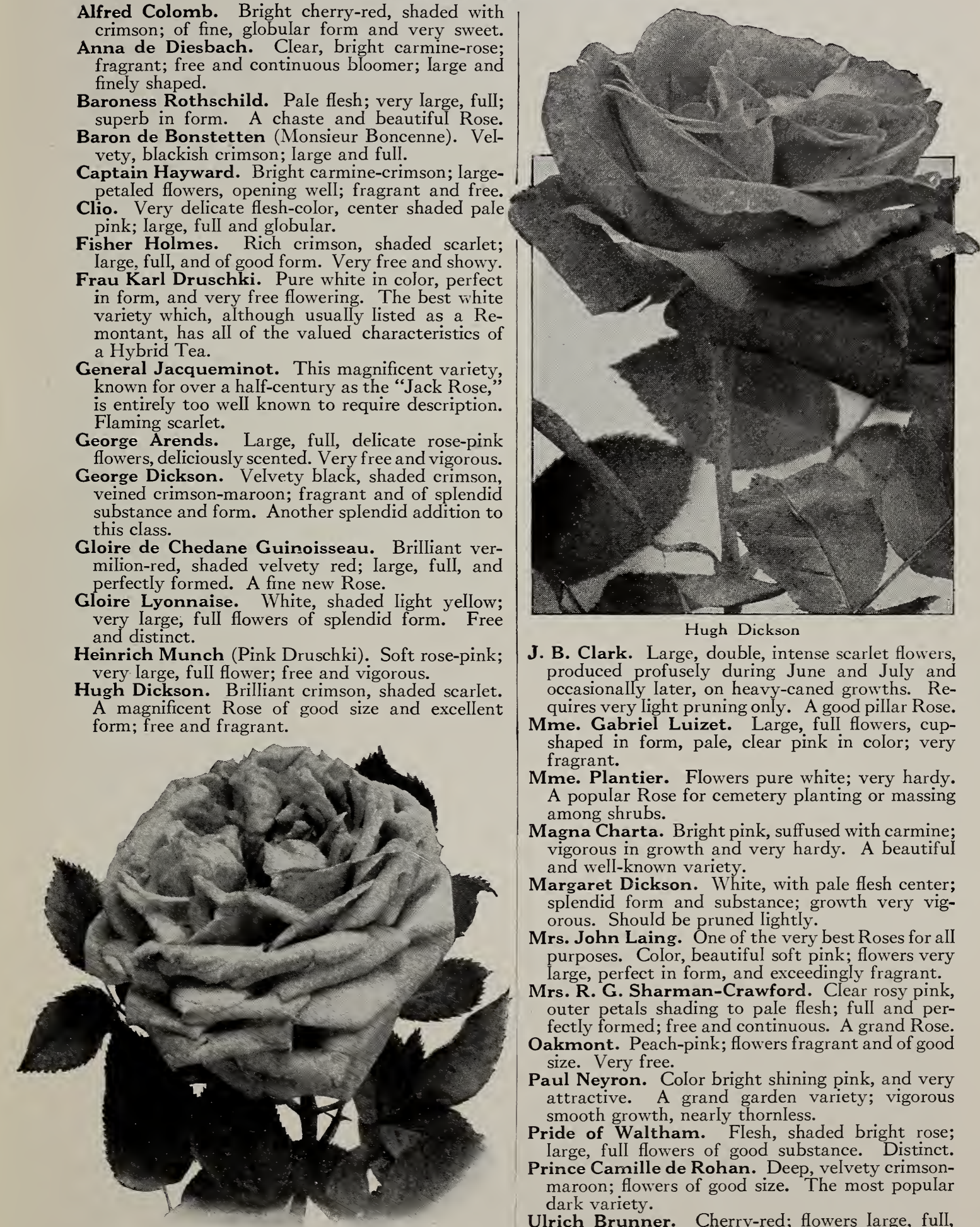

Hugh Dickson

J. B. Clark. Large, double, intense scarlet flowers, produced profusely during June and July and occasionally Iater, on heavy-caned growths. Requires very light pruning only. A good pillar Rose.

Mme. Gabriel Luizet. Large, fuII flowers, cupshaped in form, pale, clear pink in color; very fragrant.

Mme. Plantier. Flowers pure white; very hardy. A popular Rose for cemetery planting or massing among shrubs.

Magna Charta. Bright pink, suffused with carmine; vigorous in growth and very hardy. A beautiful and well-known variety.

Margaret Dickson. White, with pale flesh center; splendid form and substance; growth very vigorous. Should be pruned lightly.

Mrs. John Laing. One of the very best Roses for all purposes. Color, beautiful soft pink; flowers very large, perfect in form, and exceedingly fragrant.

Mrs. R. G. Sharman-Crawford. Clear rosy pink, outer petals shading to pale flesh; fuIl and perfectly formed; free and continuous. A grand Rose.

Oakmont. Peach-pink; flowers fragrant and of good size. Very free.

Paul Neyron. Color bright shining pink, and very attractive. A grand garden variety; vigorous smooth growth, nearly thornless.

Pride of Waltham. Flesh, shaded bright rose; large, fuIl flowers of good substance. Distinct.

Prince Camille de Rohan. Deep, velvety crimsonmaroon; flowers of good size. The most popular dark variety.

Ulrich Brunner. Cherry-red; flowers large, full, and of globular form. A hardy and free-flowering garden Rose of innumerable good qualities. 


\section{ROSA RUGOSA AND HYBRIDS}

These exceedingly hardy Roses are natives of Japan and thrive in almost any soil or situation. They are used extensively for hedging, massing among shrubbery, and seashore planting.

Dormant, 2-yr., field-grown plants, 50 cts. each, $\$ 5$ per doz., $\$ 40$ per 100 , except where noted

Blanc Double de Coubert. Large, showy, double white flowers. 75 c. ea., \$7.50 per doz.

Conrad F. Meyer. Clear silvery rose, resembling the variety $\mathrm{La}$ France; very vigorous grower; fragrant. $75 \mathrm{c}$. ea., $\$ 7.50$ per doz. Rugosa. Bright pink, single flowers.

Rugosa alba. A pure white form.

\section{AUSTRIAN BRIERS AND HYBRIDS}

These are hardy, semi-climbing, or bush Roses, requiring no pruning other than the removal of dead or surplus wood. They flower early in the season.

Strong, 2-yr., dormant plants, 75 cts. each, $\$ 7.50$ per doz.

Austrian Copper. Vivid, reddish copper; flowers single. One of the most striking and beautiful Roses grown.

Harison's Yellow. Pretty, semi-double, golden-yellow flowers. Fine to plant among other shrubs.

Juliet. Large, full flowers of novel and distinct coloring; outside of petals old-gold, interior rich, rosy red, changing to deep rose as the flower opens.

Persian Yellow. Deep golden yellow; large and fairly full; very good.

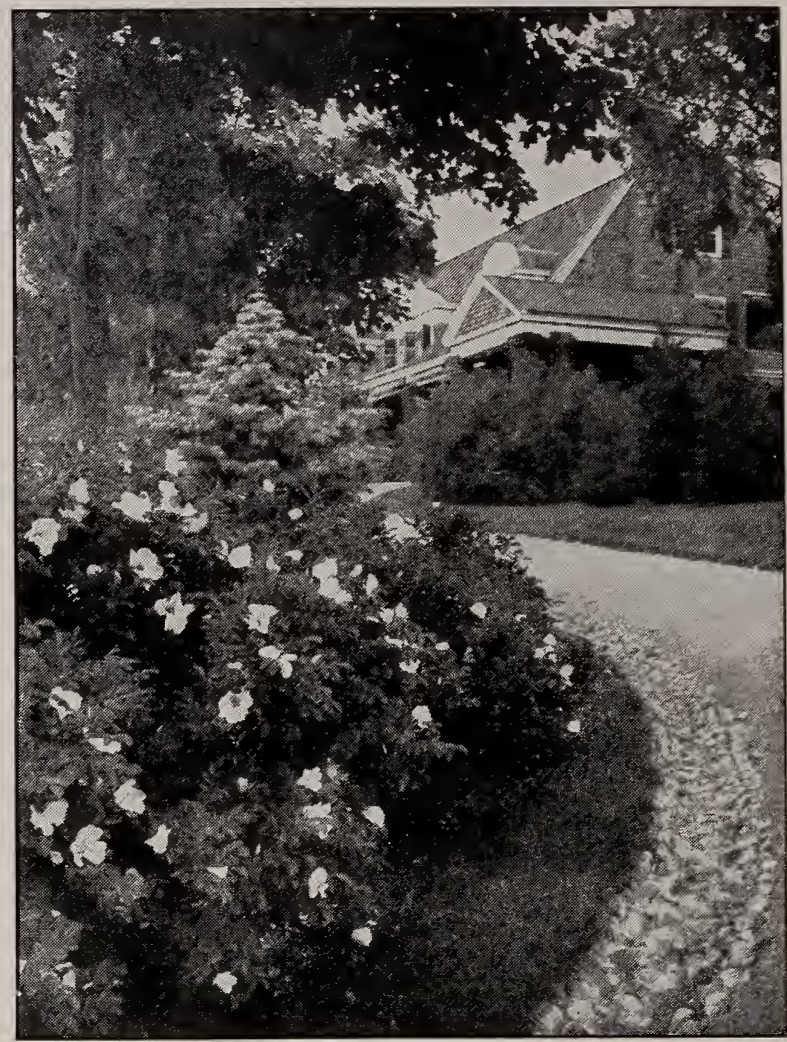

Rosa rugosa

Soleil d'Or (Sun of GoId). Orange-yellow, varying to nasturtium-red and reddish gold; large, full flowers. Very hardy.

\section{MOSS ROSES}

Roses that are very attractive in the border or shrubbery planting. They are entirely hardy, do not require severe pruning, and thrive in almost any soil. The buds are surrounded by a mossy covering that makes the flower attractive and unique.

Strong 2-yr., dormant plants, 75 cts. each, $\$ 7.50$ per doz.

Blanche Moreau. Pure white; Iarge, fuII, and very fragrant. The best of the white Moss Roses.

Crested Moss. Pink in color; very distinct.

Red Moss. Best of the type. Hardy and vigorous.

\section{HARDY CLIMBING, RAMBLER, AND MEMORIAL ROSES}

Strong, 2-year plants, 60 cts. each, $\$ 6$ per doz., $\$ 45$ per 100, except where noted

American Pillar. A very popular single hardy climber. The lovely rosy pink flowers are borne in large clusters and in such abundance as to hide the dark green, leathery insect-proof foliage. Grows 20 feet in a season.

Christine Wright. This beautiful new Wichuraiana hybrid, of which the variety Caroline Testout is a parent, takes its fine color-a bright wild-rose-pink -from the latter, and in part, the form, which is quite double and from $31 / 2$ to 4 inches in diameter. The flowers are produced in quantities, coming singly and in clusters.

Climbing American Beauty. A fine, free-blooming climber of excellent habit. Strong and vigorous in growth, making heavy canes from io to 15 feet in a single season. Rosy crimson flowers, produced freely in June and occasionally throughout the season; very fragrant. A fine Rose.
Crimson Rambler. Well known and very popular. A strong, rank grower that produces heavy trusses of brilliant, double, crimson flowers in great profusion.

Dorothy Perkins. A splendid variety with bright, glossy foliage that always looks healthy, and beautiful clusters of pink flowers.

Dr. W. Van Fleet. Flesh-pink, deepening to rosy flesh in the center. The flowers are fuII, very double, and carried on good stems, resembling Souvenir du President Carnot (one of the parents) in color.

Elizabeth Zeigler." Wichuraiana Hybrid. A sport of the climbing Rose, Dorothy Perkins, but a superior variety in every respect. The color is a delightful shade of deep rose-pink, a most effective garden color and one that has been lacking heretofore among the climbing Roses. 


\section{HARDY CLIMBING, RAMBLER, AND MEMORIAL ROSES, continued}

Evangeline. Very dainty, single flowers, the center being white half-way up the petals, shading to a beautifuI pink.

Evergreen Gem. Buff, changing to creamy white; very double flowers; delicately perfumed; handsome foliage.

Excelsa (Red Dorothy Perkins). Has the dark, glossy, disease-resisting foliage peculiar to the Wichuraiana type. The growth is very vigorous and healthy in appearance, resembling in this respect Dorothy Perkins. Flowers are very double, produced in large trusses of thirty to forty blossoms. The color is intense crimson-maroon, tinged scarlet on the edges of the petals.

Gardenia. Bright yellow, becoming paler as flower expands. Blooms profusely and is very vigorous. A desirable variety.

Goldfinch. Soft yellow, changing to Iemon-yellow and white as the flowers age. Very free and distinct. One of the best in this color.

Hiawatha. The most brilliant-colored single Rose -bright carmine, with a clear white eye and a mass of golden stamens. A glowing combination of color and a variety you must know to appreciate.

La Fiamma. Large clusters of flame-colored flowers, carried on strong stems. PIants hardy and vigorous, making a growth of 15 feet in a season.

Lady Gay. Vigorous in growth, with flowers of delicate cerise-pink in heavy clusters. The combination of deep pink buds, shading to softer pink in the open flower, and glossy green foliage, makes this variety one of the most charming of the Ramblers.

Moschata alba. Single white flowers, distinct golden center; in graceful clusters. Fine pillar Rose.

Newport Fairy. With flowers of deep pink, shading lighter toward the center, this is one of the most valuable single Roses. Its large clusters are borne in great profusion and the variety is a strong grower. Extralarge size, \$I each, \$Io per doz.

Paul's Carmine Pillar. Large, single, bright rosy carmine flowers, appearing earlier than other climbing Roses. A showy pillar Rose. 75 cts. each, \$7.50 per doz.

Paul's Scarlet Climber. One of the most promising climbing Roses yet sent out. Vivid scarlet, semi-double flowers of medium size, produced in Iarge clusters and in great profusion. Does not burn or fade. Exhibited extensively in Europe and received $\mathrm{numerous}$ awards. Strong, 2-yr. plants, \$I.50 each.

Purity. This magnificent new Rose resembles Silver Moon but is superior in many respects. Growing beside that variety, under identical conditions in the Hartford Test-Gardens (where it was awarded a silver medaI, I9I5), it is equally Iuxuriant in growth but much freer in flowering, never producing blind wood, and it stands extreme weather conditions better. Strong plants, \$I each; extra-heavy plants, \$I.50 each.
Rosiere. A great improvement on the popular Thousand Beauties (Tausendschön). The color is superior-a deeper and more even shade of cerisepink or carmine. Those who have admired Thousand Beauties will surely add this improved variety to their collection. Selected, 2-yr. plants, \$I each; extra-large, 3-yr. plants, \$1.50 each.

Silver Moon. This new Rose is of the same strong growth as Dr. W. Van Fleet. Foliage beautiful bronze-green, mildew-proof. Flowers are very large, and produced on strong stems. Color silvery white, with prominent yellow stamens. Very fragrant and attractive. Extra-large size, \$I each, \$io per doz.

Sodenia. A scarlet Wichuraiana, producing its flowers in Iarge trusses, like Dorothy Perkins, and in great profusion.

Tausendschon. An entirely distinct Rose. The individual flowers are large and of a most elegant and graceful form. In color, a most delightful shade of soft pink, deeper in bud form and lighter when fully open.

White Dorothy Perkins. A counterpart of Dorothy Perkins, except in color, showing a faint trace of pink in bud, opening to a pure white flower 


\section{PEONIES · IRIS ROSES}

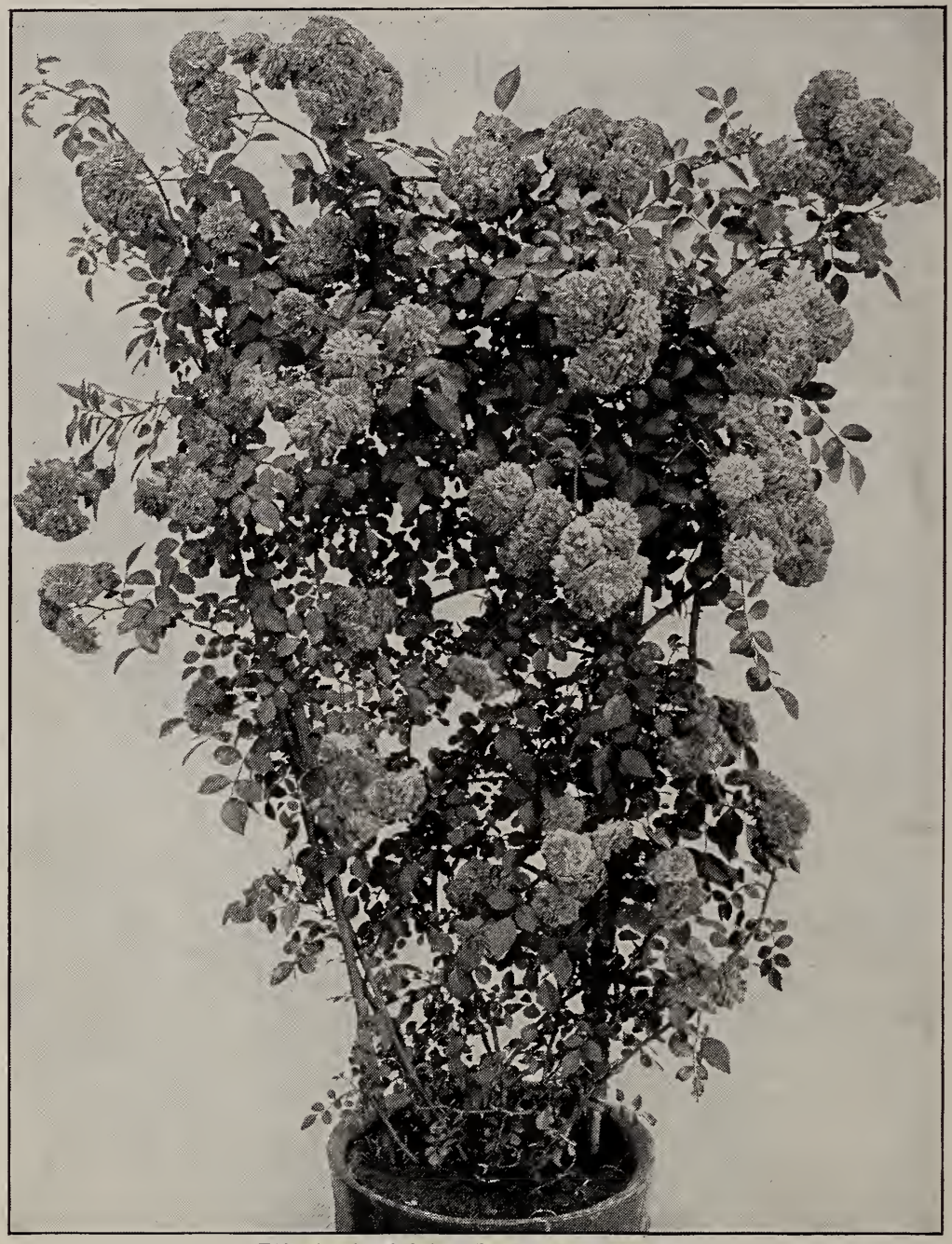

Elizabeth Zeigler Rose (see page 14)

\section{CromWell GARDENS}

A. N. PIERSON, Inc.

CROMWELL

CONNECTICUT 